\title{
The Effect of Book-Tax Differences, and Executive Compensation on Earnings Persistence with Real Earnings Management as Moderating Variable
}

\author{
Zuhal Maftuh Ahnan, Etty Murwaningsari \\ Faculty of Economics and Business Trisakti University, \\ Jl. Kyai Tapa No.1, Tomang, Grogol Petamburan, West Jakarta, Jakarta 11440, Indonesia
}

\begin{abstract}
This study analysed the effect of book-tax differences, and executive compensation for earnings persistence with real earnings management as moderating variables. The panel data is 192 samples from the Banking sector which were listed on the Indonesia Stock Exchange in 2014-2017. Use multi regression moderation analysis. The results show that current tax, permanent differences, and temporary differences have a significant positive effect on earnings persistence, executive compensation has a significant negative effect with earnings persistence, and cash flows operations have a positive and insignificant effect on earnings persistence. The results of the moderating variable test, real earnings management weaken the influence of current tax and permanent differences on earnings persistence. The effect of cash flows operations, temporary differences and compensation on earnings persistence is strengthened by real earnings management.
\end{abstract}

Keywords: Book-Tax Differences, Executive Compensation, Earnings Management, Earnings Persistence. Permanent Different, Temporary Different, Cash Flow Operations.

DOI: $10.7176 /$ RJFA/10-5-05

Publication date:March $31^{\text {st }} 2019$

\section{Introduction}

Profits obtained by a company can used as a basis for evaluating the company's financial performance. Internal and external companies use profits as a basis for decision-making such as investment decisions, monitoring performance awards, and contracting (Almadi and Lazic, 2016). Managerial power theory argues that executive salaries do not correlate with performance. In other words, high-income people are not always high-performing. This breakdown of the relationship between ownership and control raises the risk that the person controlling the company may not have the same interests as the people who own the company. One of the performance awards and contract making related to executive compensation that management will give to top managers. Cheng and Warfield (2005) document higher levels of earnings management to meet or beat analyst estimates in companies with greater executive equity incentives. That the size of discretionary accrual is greater in companies where manager's wealth is more closely related to stock values (Bergstresser and Philippon, 2006; Burns and Kedia, 2006). Real activity manipulation is usually targeted at short-term stock performance, but it is not useful for increasing company value or increasing company cash flow, shows that accrual-based earnings management measures (Roychowdhury, 2006; Bhojraj et.al, 2009)

Agency theory in earnings management practices influenced by existence of a conflict of interest between the agent and the principal that arises when each party strives to do or support the desired level of prosperity. The existence differences in interests and information between principles and agents spur agents to think about how the accounting numbers produced can maximize their interests (Morgenson, 2013). The tendency of the existing literature sees that for increasing value and performance the company uses real earnings management (REM) to meet these targets on annual analyst estimates (Järvinen and Myllymäki, 2016, Roychowdhury, 2006). In expansion to making REM to estimate firm value, it also strengthens the effect of REM on company performance (Machdar, Manurung, Murwaningsari, 2017).

In addition to different measurements in earnings manipulation, there are also differences in time and related costs between real-based and accrual-based. REM must realized amid the monetary year, as contradicted to accrual-based, as opposed to accrual-based earnings management which still have opportunity to control after the conclusion of the monetary year ((Zang, 2012; Zarowin, 2010; Barton, 2001; Cohen). The difference between this research and earlier research is the role of REM as a moderating variable expected to weaken influence of current before-tax and temporary differences and strengthen influence of cash flows operating, permanent differences and executive compensation on the following year's tax return.

The aims of this study are: 1) the effect of current tax on earnings persistence. 2) the effect of cash flows operation on earnings persistence. 3) the effect of permanent difference on earnings persistence. 4) the effect of temporary differences on earnings persistence. 5) the effect of executive compensation on earnings persistence. 6) the effect REM as a moderating variable between of current earnings on earnings persistence. 7) the effect REM as a moderating variable between cash flows operating on earnings persistence. 8) the effects REM as a 
moderating variable between permanent differences on earnings persistence. 9) the effect REM as a moderating variable between temporary differences on earnings persistence. 10) the effect REM as a moderating variable between of executive compensation on earnings persistence.

\section{Literature Review and Hypotheses Development \\ 2.1 Literature Review}

\subsubsection{Earnings Persistence}

Earnings persistence (EP) is measured to be a proxy for earnings quality (Dechow et al., 2010). Higher quality earnings provide more information about the company's financial performance features that are relevant to specific decisions made by certain decision makers. Taxable income on accounting income is a measure of quality of income and hence contains additional information about accruals and cash flows (Lev and Nissin, 2004). Accruals increase earnings persistence compared to cash flows for companies with large size accruals, but accruals reduce earnings persistence compared to cash flows for firms with small size accruals (Dechow and Ge, 2006; Blaylock et al., 2012)

\subsubsection{Cash Flows Operating}

Cash Flows Operating (CFO) called the amount of cash arising from the company's operations on income, expenses, income and expenses. CFO describes how companies earn income and convert it into cash, earnings persistence is also determined by the components of cash flow contained in current income (Waluyo, 2016; Brown et.al, 2010; Penman, 2001).

\subsubsection{Permanent Differences}

Permanent difference arise when certain income and expenses recognized by accounting principles, but are not based on tax regulations. Permanent differences usually arise because tax laws must that some transactions not be included calculation of taxable income (Sundvik, 2017; Martinez and de Souza, 2012)

\subsubsection{Temporary Differences}

Temporary differences occur when both accounting rules and tax laws recognize the same number of transactions, however, they differ with respect to the time of this recognition. A transaction can recognized by accounting principles, but not by tax regulations; or vice versa. Temporary differences are usually caused by differences in the methods used by accounting rules and tax rules, in terms of accrual and their realization, depreciation and amortization, inventory valuation, and compensation calculations (Sundvik, 2017; Jackson, 2009).

2.1.5 Executive Compensation

Compensation is a reward or remuneration for employee performance manifested in financial and non-financial terms. These rewards can in the form of salaries, bonuses, stock options, restricted shares, pension funds, and other benefits (Neokleous, 2015). Compensation given can motivate and improve agent performance which will have an impact on increasing company performance (Awuor 2012). Compensation is also useful for maintaining a competent workforce in managing the company (Anthony and Govindarajan 2007).

\subsubsection{Real Earnings Management (REM)}

Real activity manipulation is usually targeted at short-term stock performance, but it is not useful for company value or increasing company cash flow, shows that accrual-based earnings management measures (Roychowdhury, 2006; Bhojraj et.al, 2009), in a reverse way to meet revenue targets, such as zero profit or annual analyst estimates and to avoid a bad market reaction, there arises a REM (Roychowdhury, 2006; Järvinen and Myllymäki, 2016).

\subsection{Hypotheses Development}

\subsubsection{The effect of current tax on earnings persistence}

Book-tax differences as a negative signal of EP (Blaylock et al., 2012; Hanlon, 2005 ), for companies it is likely that management has exploited the gap in accounting standards with tax regulations so that earnings management occurs, so if BTD becomes a signal of increased accrual processes then the company with Large BTD will show lower earnings and accrual persistence. Hanlon (2005) states that there are still several factors that support and show that book-tax differences can show information about earnings persistence. In the Hanlon (2005) study, Wijayanti (2006) also proved that companies with large positive taxation (negative) significant negative effect on earnings persistence.

Hypothesis 1: Current tax has a negative effect on earnings persistence.

\subsubsection{The effect of operating cash flow on earnings persistence}

Operating cash flow (CFO) can be called the amount of cash arising from a company's operations on income, expenses, income and expenses. The CFO describes how the company earns income and converts it into cash. Persistence of earnings is also determined by the components of cash flow contained in current income (Jackson, 2015; Penman, 2001).

Hypothesis 2: Operating cash flow has a positive effect on earnings persistence 


\subsubsection{The effect of permanent differences on earnings persistence}

Martinez and de Souza (2012), permanent differences occur because of differences in recognition between accounting rules and tax regulations related to certain income and expenditure. Permanent differences arise when certain income and expenses recognized by accounting principles, but are not based on tax regulations. Permanent differences result in a permanent difference between accounting earnings and taxable income. Permanent differences usually arise because tax laws must that some transactions not be included calculation of taxable income. According to the Income Tax Act, some items which constitute a permanent difference are final income tax (Article 4 paragraph 2), non-taxable objects (Article 4 paragraph 3), and costs that are not allowed gross income (Article 9). paragraph 1) (Waluyo, 2016).

Hypothesis 3: Permanent differences have a positive effect on earnings persistence

2.2.4 The effect of temporary differences on the persistence of earnings

Temporary differences occur when accounting rules and tax laws recognize the same number of transactions, however, differing with respect to the time of recognition. A transaction recognized by accounting principles, but not by tax regulations; or vice versa (Sonnier et al., 2012). This difference is temporary because it identified in the next accounting period. In other words, all transactions are actually recognized by the accounting system and taxes but they differ with regard to the time of their allocation. Temporary differences are usually caused by differences in the methods used by accounting rules and tax rules, in terms of accrual and realization, depreciation and amortization, inventory valuation, and calculation of compensation for losses (Noor et al., 2009).

\section{Hypothesis 4: Temporary differences negatively affect on earnings persistence}

\subsubsection{The effect of executive compensation on earnings persistence}

The managerial view of power states that CEO compensation and other corporate governance practices reflect the exercise of managerial power and behavior more than providing efficient incentives. Bonus payments all BOD regularly halt as a punishment when the company's execution break down or when a outrage including company administration uncovered. Compensation is also useful for maintaining a competent workforce in managing the company (Anthony and Govindarajan 2007). Balsam (1998) said that company supervisors utilize profit administration as it were when benefits surpass costs.

Hypothesis 5: Executive compensation has a negative effect on earnings persistence

2.2.6 The effect REM as a moderating variable between of current earnings on earnings persistence.

The way an agent can do to influence accounting numbers profit engineering or earnings management in financial statements. Current tax burden and large deferred tax burden will reduce the level of profits obtained by a company, and vice versa, the current tax burden and small deferred tax burden will increase the level of profits obtained by a company. Income consists of accrual and cash flows. Juliati and Tjaraka's research (2014) proves that the tax burden now has ability to detect REM also finds a weak result that there is an earnings management action on the company consideration of the income tax burden.

Hypothesis 6: REM weakens the effect of current tax profits on earnings persistence

\subsubsection{The effect REM as a moderating variable between cash flows operating on earnings persistence}

Dechow and Ge (2005), mentions operating cash flows related to company processes in generating operating profits from aspects of cash transactions. Cash income and expenditure will affect the company's profit figures such as when cash sales or payment of expenses that go directly out of cash. Evaluation of earnings and cash flow is sensitive to the economic characteristics of the company (Watson and Wells, 2005). Profits compiled on accrual basis contain elements of manager's interest in the reporting so that information on operating cash flows needed as one of the considerations in predicting the company's performance in the future. Fairfield et al. (2003), using operating cash flow as one of the predictive components of the company's future operating profit.

\section{Hypothesis 7: REM strengthens the effect of operating cash flows on earnings persistence}

2.2.8 The effects REM as a moderating variable between permanent differences on earnings persistence The difference between book and taxable income may not be informative about earnings management or crosssectional variation in generating earnings persistence. On the other hand, with tax conformation the second book of financial accounting and tax systems is separated (Goncharov and Zimmermann, 2006).

Hypothesis 8: REM weakens the effect of permanent differences on earnings persistence

2.2.9 The effect REM as a moderating variable between temporary differences on earnings persistence

Book-tax differences generated by tax planning strategies. Book-tax conformity is consistent with the general system for accounting and taxation purposes, where financial accounting is directly used to calculate taxable profits. The difference in book-tax classified as temporary differences (Hanlon and Shevlin, 2008). Temporary differences defined as items included in book income or tax income but which included in both according to the time of use.

Hypothesis 9: REM strengthens the effect of temporary differences on earnings persistence 2.2.10 The effect REM as a moderating variable between of executive compensation on earnings persistence Balsam (1998), that shareholders tend to remunerate supervisors who utilize optional discretionary accrual 
smoothing. Smoothing anticipated to diminish detailed instability in net pay and offer assistance company directors to defeat income targets in a push. Hence, the relationship between official rewards and optional collection is moderately higher when company supervisors utilize optional collection for salary smoothing. This appears a shifted relationship between optional gathering and official rewards.

Hypothesis 10: REM strengthens the effect of executive compensation with earnings persistence

\section{Research Methodology}

\subsection{Population dan Sample}

Population uses secondary financial statement data from public banking companies listed on the Indonesia Stock Exchange. This study uses non-random sampling technique, namely purposive sampling. The total banking 48 companies, the observation period from 2014-2017 was 4 years so that 192 observations obtained.

\subsection{Research Model}

To estimate earnings persistence, use equation one (1). Previous research (Blaylock et al., 2012; Hanlon, 2005) in which persistence estimated through pre-tax book income over the next year. In this model, PTBI represents profit before tax, estimated for the coming period, divided by the average total (TA) assets so that the model equation is as follows:

$$
\begin{aligned}
P_{T B I_{t+1}=} & \alpha+\beta 1 P T B I_{t}+\beta 2 C F O+\beta 3 P E R M+\beta 4 T E M P+\beta 5 C O M P+\beta 6 R E M+\beta 7 P T B I t^{*} R E M+\beta 8 C F O * R E \\
& M+\beta 9 P E R M^{*} R E M+\beta 10 T E M P^{*} R E M+\beta 11 C O M P^{*} R E M+\beta 12 R O A+\beta 13 S A L E S+ \\
& \beta 14 C E T R+\beta 15 S I Z E+\beta 16 L E V+\varepsilon
\end{aligned}
$$

PTBI $\mathrm{t}+1=$ Pretax Book Income (Profit Before Tax) in the period $\mathrm{t}+1$; PTBI $\mathrm{t}=$ Pretax Book Income (Profit Before Tax) in the period t; CFO $t=$ Operating Cash Flows; PERM (permanent difference); TEMP (temporary difference); COMP (executive compensation) REM. ROA (Return On Assets); SALES ; CETR (Current Effective Tax Rates), SIZE dan LEV (Leverage).

\subsection{Variable Measurement}

Pre-tax book income (PTBI t ) is pre-tax income as measured by TA (Sundvik, 2017; Dridi dan Adel, 2016; Hanlon, 2005). Operating cash flow (CFO) referred to as the amount of cash arising from a company's operations on income, expenses, income and expenses. CFO describes how companies earn income and convert it into cash (Conyon and He, 2012; Carter and Hillegeist, 2010; Penman, 2001). Permanent differences (PERM) obtained from accounting earnings and taxable income. Permanent differences arise because tax laws must that some transactions not be included calculation of taxable income (Sundvik, 2017; Waluyo, 2016; Martinez et. Al, 2016; Martinez and de Souza, 2012). Temporary differences (TEMP) obtained due to differences in the rules of both accounting rules and tax laws recognizing the same number of transactions, however, they differ with respect to time of recognition. A transaction recognized by accounting rules, but not by tax regulations; or vice versa. For example, accruals and realization, depreciation and amortization, inventory valuation, and compensation calculations (Sundvik, 2017; Waluyo, 2016; Martinez et.al, 2016; Jackson, 2009). Executive compensation (COMP) is Natural log compensation (basic salary, cash bonus, benefits, etc.) Carter and Hillegeist (2010), Conyon and He (2012).

Dependent variable, earnings persistence (PTBIt +1$)$ is taxable income divided by average TA. Previous research Blaylock et al., 2012; Hanlon, 2005). Moderating variables, REM are measured by the number of abnormal provisions for loans / or loss of assets, abnormal cash flows and abnormal discretionary expenditure equations. REM banks are measured by the size of Robb (1998) combined with measurements of Roychowdhury (2006), as used by Chou \& Chan (2018) where:LLPi.t/ TAi.t $=$ LLPi. $^{\text {t-1/ }}$ TAi.t + WOi.t/ TAi.t + WOi.t+1/ TAi.t,

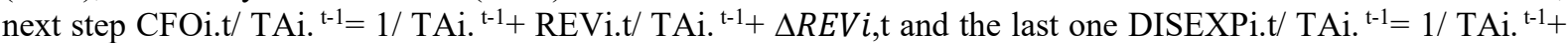
REVi. ${ }^{\mathrm{t}-1} / \mathrm{TAi}^{\mathrm{t}-1}$, LLPi, $\mathrm{t}$ and LLPi, $\mathrm{t}-1$ are bank provisions for loans / or asset losses against TA in year $\mathrm{t}$ and $\mathrm{t}-1$, respectively; WOi, $\mathrm{t}$ and WOi, $\mathrm{t}+1$ is Net Charge-Off bank i to TA in the year $\mathrm{t}$ and $\mathrm{t}+1$, respectively; TAi, $t$ is the TA of the bank in the year $\mathrm{t}$. Estimated error term $\theta \mathrm{i}$, $\mathrm{t}$ are unexpected provisions for loans / or asset losses, i.e. abnormal provisions for loans / or loss of assets for i bank year t. CFOi, $t$ is cash flow from bank operations $\mathrm{i}$ year $\mathrm{t}$; $T A i, t-1$ is TA bank i year $\mathrm{t}-1 ; R E V i, t$ is total income from the bank i during the year $\mathrm{t} ; \Delta R E V i, t$ is the change in income from banks in the year $\mathrm{t}$; estimate $\mathrm{yi}, \mathrm{t}$ is an estimation error term, used as a measure of abnormal cash flow for $\mathrm{i}$ bank.DISEXP $i t$ the bank is discretionary spending $\mathrm{i}$ year $\mathrm{t}$, which is defined as the amount of advertising costs, and sales, general and administrative costs; estimate $\delta \mathrm{i}$, $\mathrm{t}$ is a term estimate of error, that is abnormal discretionary costs for $\mathrm{i}$ bank.

The control variable consists of: company size (SIZE) which is measured by the natural logarithm of TA (Hung et.al, 2018; Liu and Schneible, 2017; Koubaa and Jarboui, 2017), LEVERAGE measured by Total liabilities / TA (Hung et.al, 2018; Koubaa and Jarboui, 2017), Return On Assets (ROA) obtained from profit before tax / average TA (Hung et.al, 2018; Koubaa and Jarboui, 2017), SALES obtained from current year's sales / average TA (Hung et.al, 2018), effective tax rate at this time (CETR) obtained from current tax income / 
pre-tax profit (Zhou, 2016, Xian et.al, 2016; Hanlon, 2005).

\section{Results and Discussion \\ 4.1 Descriptive Statistics}

Table 1 show that the Pretax Book Income in the next period $t+1($ PTBIt +1$)$ has an average of 0.005 . With positive earnings persistence, it important role in assessing company performance. The highest PTBIt +1 (maximum) is 0.109 and the lowest (minimum) is 0,000 and the std.dev is 0.010 . The minimum value of Pretax Book Income in the current period (PTBIt) is 0,000 , while the average value is 0.019 or $1.9 \%$. The std.dev value is 0.018 , which indicates variations in the homogeneous PTBIt. The average PTBIt value is greater than the std.dev value which indicates that PTBIt +1 gives a large response from the profit information generated at PTBIt.

The average operating cash flow is smaller than the std.dev, which indicates that the company uses operating cash flows with an average value of 0.012 to improve the following year's pre-tax profit. Executive compensation (COMP) shows the minimum value of 6.486 stated by the company. The std.dev value of 1.574 which indicates the type of compensation executive is homogeneous. The average value of executive compensation is 10.283 with a std.dev value lower than the average value so that the average value used as a benchmark for presentation in the entire data.

The average REM is higher than the std.dev value, indicating that the company uses REM with an average value of $7.2 \%$ of the following year's profit before tax, while the average permanent difference value (PERM) and temporary difference (TEMP) is smaller than the std.dev value, indicating that the company uses permanent and temporary differences with an average value of $1 \%$ and less than $1 \%$ of the following year's pre-tax profit.

The minimum return on assets (ROA) value of -11.50 recorded by the company, the average return on assets value is 1.011 with a std.dev value of 2.407 which indicates that the type of return on assets is homogeneous. The average value of return on assets is greater than the value of the std.dev of the company, which indicates that the company responds to tax returns the next year responds more to information on earnings return on assets. Sales (SALES) sets a minimum value of 0.022 while the average value is 0.097 . The average value of earnings for the following year is 0.005 , which means that the company has the following year's pre-tax profit of $0.5 \%$ on the TA. The average value of current tax effectiveness (CETR) is 0.250 so that the company uses that effectiveness to control the company's activities and is also implied by the average bank company to see the following year's pre-tax profit.

\begin{tabular}{|c|c|c|c|c|c|}
\hline Variables & Mean & Med. & Max. & Min. & Std. Dev. \\
\hline PTBIt+1 & 0,01 & 0,00 & 0,11 & 0,00 & 0,01 \\
\hline PTBIt & 0,02 & 0,02 & 0,11 & 0,00 & 0,02 \\
\hline $\mathrm{CFO}$ & 0,01 & 0,02 & 0,22 & $-0,22$ & 0,07 \\
\hline PERM & 0,00 & 0,00 & 0,03 & $-0,01$ & 0,00 \\
\hline TEMP & 0,00 & 0,00 & 0,04 & $-0,11$ & 0,01 \\
\hline COMP & 10,28 & 10,06 & 13,14 & 9,49 & 1,57 \\
\hline REM & 0,07 & 0,06 & 0,26 & 0,01 & 0,05 \\
\hline ROA & 1,01 & 1,18 & 10,77 & $-11,15$ & 2,41 \\
\hline SALES & 0,10 & 0,09 & 0,19 & 0,02 & 0,02 \\
\hline CETR & 0,25 & 0,24 & 4,79 & 0,00 & 0,40 \\
\hline SIZE & 17,03 & 16,83 & 20,84 & 13,52 & 1,83 \\
\hline LVG & 0,85 & 0,86 & 0,97 & 0,61 & 0,05 \\
\hline
\end{tabular}

Note : PTBIt+1 : pretax book income one-year ahead, PTBIt: pretax book income for the current year, PTCF: pretax cash from operations, PERM: Permanent book-tax difference, TEMP: Temporer book-tax difference, COMP: Executive Compensation, REM, ROA: Return On Assets, SALES: Sales in year, CETR: Current Effective Tax Rates, SIZE: Firm Size, LEV: Leverage

The average value of company size (SIZE) is 17,031 , the next year's average tax profit value is 0.01 , which means that the company's operating activities range from $1 \%$ of the TA. The average leverage value (LEV) is greater than the std.dev, so the implication is that the leverage level is around $85 \%$ to provide information to stakeholders in their business strategy management.

\subsection{Correlation Matrix}

The correlation matrix shown in table 2 reveals current pre-tax profit (PTBIt), operating cash flow (CFO), fixed difference $(\mathrm{PERM})$, temporary difference (TEMP) and next year's pre-tax profit (PTBIt +1$)$ significant correlation. This correlation shows that the higher component of the difference in tax and accounting income the higher the taxable profit the following year or vice versa. In conclusion, a significant correlation between variables is complementary. 
Table 2. Correlation Matrix

\begin{tabular}{|c|c|c|c|c|c|c|c|c|c|c|c|c|}
\hline Variable & PTBIt+1 & PTBIt & $\mathrm{CFO}$ & PERM & TEMP & COMP & REM & ROA & SALES & CETR & SIZE & LEV \\
\hline PTBIt+1 & 1 & & & & & & & & & & & \\
\hline PTBIt & 0,26 & 1 & & & & & & & & & & \\
\hline $\mathrm{p}$-value & $0.00^{* * *}$ & & & & & & & & & & & \\
\hline $\mathrm{CFO}$ & $-0,22$ & $-0,22$ & 1 & & & & & & & & & \\
\hline $\mathrm{p}$-value & $0,02 * *$ & $0,02 * *$ & & & & & & & & & & \\
\hline PERM & 0,30 & 0,30 & 0,20 & 1 & & & & & & & & \\
\hline $\mathrm{p}$-value & $0,09^{*}$ & $0,09^{*}$ & 0,14 & & & & & & & & & \\
\hline TEMP & 0,14 & 0,14 & 0,22 & $-0,08$ & 1 & & & & & & & \\
\hline $\mathrm{p}$-value & $-0,01 * *$ & $-0,01 * *$ & $-0,33$ & $-0,01^{* *}$ & & & & & & & & \\
\hline COMP & 0,01 & 0,01 & $-0,01$ & $-0,07$ & 0,11 & 1 & & & & & & \\
\hline $\mathrm{p}$-value & $0,00^{* * *}$ & $0,00 * * *$ & 0,71 & 0,15 & 1,00 & & & & & & & \\
\hline REM & 0,23 & 0,23 & $0,09^{*}$ & $0,10^{*}$ & 0,11 & 0,15 & 1 & & & & & \\
\hline p-value & $-0,83$ & $-0,83$ & 0,36 & $0,07^{*}$ & 0,15 & 0,34 & & & & & & \\
\hline ROA & $0,00^{* * *}$ & $0,00 * * *$ & 0,39 & 0,30 & 0,23 & 0,30 & $0,01 * *$ & 1 & & & & \\
\hline p-value & 0,09 & 0,09 & $0,03^{* *}$ & $0,01 * *$ & 0,36 & $0,06^{*}$ & $0,07 *$ & & & & & \\
\hline SALES & $-0,02$ & $-0,02$ & 0,08 & 0,06 & 0,09 & 0,07 & 0,03 & $0,03^{*}$ & 1 & & & \\
\hline p-value & $0,01 * *$ & $0,01 * *$ & 0,22 & $0,08^{*}$ & 1,00 & 0,11 & 0,23 & $0,09 *$ & & & & \\
\hline CETR & $-0,20$ & $-0,20$ & $-0,02$ & $-0,07$ & 0,10 & $-0,10$ & 1,00 & 0,01 & 0,03 & 1 & & \\
\hline$p$-value & 1,00 & 1,00 & $0,08^{*}$ & $0,07^{*}$ & 0,30 & $0,06^{*}$ & $0,07^{*}$ & 0,11 & $0,05^{* *}$ & & & \\
\hline SIZE & 0,21 & 0,21 & 0,15 & $-0,11$ & 0,11 & 0,83 & $-0,15$ & 0,36 & $-0,07$ & $-0,15$ & 1 & \\
\hline p-value & $0,04 * *$ & $0,04 * *$ & 0,22 & $0,01 * *$ & 0,39 & $0,08^{*}$ & $0,02 * *$ & 0,15 & $0,10^{*}$ & 0,30 & & \\
\hline LEV & $-0,08$ & $-0,08$ & 0,10 & 0,05 & 0,15 & 0,10 & 0,02 & $-0,06$ & 0,01 & 0,02 & 0,17 & 1 \\
\hline $\mathrm{p}$-value & 0,56 & 0,56 & 0,30 & 0,18 & 0,17 & 0,20 & $0,02 * *$ & 0,20 & 0,21 & $0,08^{*}$ & $0,10^{*}$ & \\
\hline
\end{tabular}

***Significant at a level 1 percent, ${ }^{* *}$ Significant at a level 5 percent, $*$ Significant at a level 10 percent

Note : PTBIt+1 : pretax book income one-year ahead, PTBIt: pretax book income for the current year, PTCF: pretax cash from operations, PERM: Permanent book-tax difference, TEMP: Temporer book-tax difference, COMP: Executive Compensation, REM, ROA: Return On Assets, SALES: Sales in year, CETR: Current Effective Tax Rates, SIZE: Firm Size, LEV: Leverage

\subsection{Result}

From table 3, the results of the classic assumption of residual normality test are: fallow finger value of 0.313 with $\mathrm{p}$ value of 0.054 where $>0.05$ so that means the residual is normally distributed. The coefficient of determination on Adjusted R-squared is 0.717 , which means $71.7 \%$ can predict the effect of independent variables on the dependent variable and $28.3 \%$ is explained by other variables outside the tested variable. Based on the partial regression test presented in table 3, tax income now has a significance value of $0,000<0,005$ and a 
regression coefficient of 0,996 , which means that tax returns are now positive and significant at levels below $1 \%$. So that hypothesis 1 is accepted, which indicates that tax profits now have an influence on earnings persistence. Operating cash flow has a significance value of $0.406>0.005$ and a regression coefficient of 0.001 , which means that operating cash flows are positive and not significant. So that hypothesis 2 is rejected, which indicates that the operating cash flow has no effect on earnings persistence. Permanent differences have a significance value of $0,000<0,005$ and a regression coefficient of 1,020 , which means that positive permanent differences are significant at levels below 1\%. So that hypothesis 3 is accepted, which indicates that permanent differences have an influence on earnings persistence. Temporary differences have a significance value of $0,000<0,005$ and a regression coefficient of 0,983 , which means that positive and significant temporary differences. So that hypothesis 4 is rejected, which indicates that operating cash flows have the opposite effect on earnings persistence. Executive compensation has a significance value of $0.029<0.005$ and a regression coefficient of 0.001 , which means that executive compensation is negative and significant at levels below 5\%. So that hypothesis 5 is accepted, which indicates that executive compensation has a negative influence on earnings persistence.

Table 3. The Effect of Book-Tax Dif'ferences, and Executive Compensation on Earnings Persistences with REM as Moderating Variable

\begin{tabular}{|c|c|c|c|}
\hline \multicolumn{4}{|c|}{$\begin{array}{c}\text { PTBIt }+1=\alpha+\beta 1 \text { PTBIt }+\beta 2 \text { CFO }+\beta 3 \text { PERM }+\beta 4 \text { TEMP }+\beta 5 \text { COMP }+\beta 6 \text { REM } \beta 7 \text { PTBIt*REM }+ \\
\beta 8 \text { CFO*REM }+\beta 9 \text { PERM*REM }+\beta 10 \text { TEMP*REM }+\beta 11 \text { COMP } * \text { REM }+\beta 12 \text { ROA }+\beta 13 \text { SALES }+\beta 14 \text { CETR } \\
+\beta 15 \text { SIZE }+\beta 16 \text { LEV }+\varepsilon\end{array}$} \\
\hline Variable & Predictions & Coefficient & Prob. \\
\hline $\mathrm{C}$ & & 0,01 & 0,37 \\
\hline PTBIt & $+/-$ & 0,99 & $0.00 * * *$ \\
\hline $\mathrm{CFO}$ & + & 0,00 & 0,41 \\
\hline PERM & + & 1,02 & $0.00 * * *$ \\
\hline TEMP & - & 0,98 & $0.00 * * *$ \\
\hline COMP & - & $-0,00$ & $0.02 * *$ \\
\hline REM & - & $-0,08$ & 0,10 \\
\hline PTBIt*REM & - & 0,80 & 0,19 \\
\hline CFO*REM & + & 0,08 & 0,481 \\
\hline PERM*REM & + & $-7,78$ & $0,00 * * *$ \\
\hline TEMP*REM & - & $-2,95$ & $0,00 * * *$ \\
\hline COMP*REM & + & 0,01 & 0,14 \\
\hline ROA & + & $-0,00$ & $0,00 * * *$ \\
\hline SALES & + & $-0,02$ & 0,24 \\
\hline CETR & - & 0,00 & 0,48 \\
\hline SIZE & $+/-$ & 0,00 & $0,02 * *$ \\
\hline LEV & $+/-$ & $-0,01$ & 0,24 \\
\hline R-squared & & & \\
\hline Adjusted R-squared & & & \\
\hline F-statistic & & & \\
\hline Prob(F-statistic) & & $* * *$ & \\
\hline Jarque-Bera & & & \\
\hline Probability & & & \\
\hline Durbin-Watson & & & \\
\hline
\end{tabular}

Observation 192

***Significant at a level 1 percent, **Significant at a level 5 percent, *Significant at a level 10 percent

Note : PTBIt+1 : pretax book income one-year ahead, PTBIt: pretax book income for the current year, PTCF: pretax cash from operations, PERM: Permanent book-tax difference, TEMP: Temporer book-tax difference, COMP: Executive Compensation, REM, ROA: Return On Assets, SALES: Sales in year, CETR: Current Effective Tax Rates, SIZE: Firm Size, LEV: Leverage

The test results of the REM moderation variable between current tax income and earnings persistence obtained a value of 0.996 and after being moderated to 0.803 . This shows that REM weakens the influence of current taxes with the persistence of earnings. The significant level produced is $0.183>0.05$ after being moderated so the results are not significant and hypothesis 6 is rejected, the conclusion is that the moderating value weakens the effect of current tax on earnings persistence. The effect of operating cash flow on earnings persistence which is moderated by REM the influence of operating cash flows with earnings persistence. The significant level produced is $0.481>0.05$ after being moderated so the results are not significant and hypothesis 7 is rejected, the conclusion is that the moderating value strengthens the influence of current tax on earnings 
persistence. The effect of permanent difference on the persistence of earnings which is moderated by REM obtained a value of 1.020 and after being moderated to -7.782. This shows that REM weakens the influence of permanent differences with persistence of earnings. The significant level produced is $0,000<0,05$ after being moderated so that the results are significant and hypothesis 8 is rejected, the conclusion is that the moderating value weakens the effect of current tax on earnings persistence.

The effect of temporary differences on earnings persistence which is moderated by REM is -0.001 and after being moderated to $-2,951$. This shows that REM strengthens the influence of temporary differences with persistence of earnings. The significant level produced is $0,000<0,05$ after being moderated so that the results are significant and hypothesis 9 is accepted, the conclusion is that the moderating value strengthens the effect of current tax on earnings persistence. The effect of executive compensation on earnings persistence which is moderated by REM is the value of -0.081 and after being moderated to -0.008 . This shows that REM weakens the influence of executive compensation with earnings persistence. The significant level produced is $0.114>0.05$ after being moderated so the results are not significant and hypothesis 10 is rejected, the conclusion is that the moderating value strengthens the influence of current tax on earnings persistence.

\subsection{Discussion}

The results of the first hypothesis are consistent with previous researchers by Dridi and Adel (2016) which state that tax profits now have an influence on next tax profits (persistence of earnings) because the market still considers the profits obtained can now be used as predictions for earnings in the next period considered financial information is most easily obtained without looking at all components of future earnings predictions. The results of the second hypothesis test results are not consistent with previous researchers by Jackson (2015) where the results of this test obtained have a positive but not significant effect, perhaps because the company is not consistent in classifying operating cash flows that have an inconsistency in the data presented, operating cash flows also useful for users of financial statements so that if part of forming the following year's profit has high validity then the future earnings prediction results will be directly proportional.

The results of the fourth hypothesis test are inconsistent with the research by Waluyo (2016) finding the results of the temporary difference test are negative so that it is different from the results of this study which has a positive and significant influence, this might occur because of the many perceptions of how to imply temporary difference components to carry out earnings management so that the difference between the differences obtained from accounting and tax differences varies. The test results of the REM moderation variable of five hypothesis testing, only the ninth hypothesis where temporary differences in earnings persistence reinforced by REM. This is consistent with Jackson's (2015) study, where temporary difference components are still an area that is often used as a way to make earnings management so that application of real-based earnings management will reduce the practice of earnings management a little. Of the five control variables tested, only two showed an influence on earnings persistence, namely Return On Assets (ROA) and firm size (SIZE) while sales (SALES), Current Effective Tax Rate (CETR) and Leverage (LEV) did not produce the effect significant to the next tax return.

\section{Conclusions, Limitations and Suggestions \\ 5.1 Conclusions}

The results of the first hypothesis test show that tax profits now influence on earnings persistence. The results of this study are consistent with Dridi and Adel (2016). The results of the second hypothesis test show that operating cash flow has a positive impact that is not significant to earnings persistences. The results of this study are inconsistent with Jackson (2015). The third hypothesis test results show that permanent differences have a significant positive influence on earnings persistence consistent with Waluyo (2016) and Marinez and Souza's (2012) research. The results of testing the fourth hypothesis show that temporary differences have a positive and significant effect, these results are not consistent with the research by Waluyo (2016). The results of the fifth hypothesis test show that executive compensation has a significant negative effect. This result is consistent with research by Neokleous (2015) and Auwor (2012).

The results of the REM hypothesis test as a moderating variable weaken the effect of current tax profits, permanent differences in earnings persistence, while strengthening operating cash flows, temporary differences and executive compensation against earnings persistence. But from the results of existence of moderating variables, the results that are after the hypothesis are the ninth hypothesis where temporary differences in earnings persistence strengthened by REM. This is consistent with Jackson's (2015) study. Control variables that show significant effects on earnings persistence are ROA and SIZE, while SALES, CETR and LEV are not significant.

\subsection{Limitations and Suggestions}

This research only uses banking data, so that it more trusted and generalized, for the next researcher the researcher recommends taking data not only in the banking sector so that the two can compare the results of the 
tests later. Second, this study does not include economic factors in the numbers associated with earnings persistence.

Therefore, further research can include other factors that can influence emergence of earnings persistence. REM-based research is still rarely used as the underlying thing for researchers to see the practice of earnings management, so that further research can explore the aspects of company value or earnings management-based company performance.

\section{References}

Anthony, Robert N. V. Govindarajan. (2007). Management Control System, 12Th Edition. New York: McgrawHill.

Awuor, M. M. (2012). The Relationship Between Director Remuneration And Performance Of Firms Listed In The Nairobi Securities Exchange. Working Paper, University Of Nairobi.

Balsam, S. (1998). Discretionary Accounting Choices And Ceo Compensation. Contemporary Accounting Research, 15, 229-252.

Barton, J. (2001), Does The Use Of Financial Derivatives Affect Earnings Management Decisions?, Accounting Review 76, 1-26

Bergstresser, D. And Philippon, T. (2006), "Ceo Incentives And Earnings Management”, Journal Of Financial Economics, Vol. 80 No. 3, Pp. 511-529.

Bhojraj, S., Hribar, P., Picconi, M., Mcinnis, J., (2009). Making Sense Of Cents: An Examination Of firms That Marginally Miss Or Beat Analyst Forecasts. J. Finan. 64 (5), 2361-2388.

Blaylock, B., Shevlin, T., \& Wilson, R. (2012). Tax Avoidance, Large Positive Book-Tax Differences, And Earnings Persistence. The Accounting Review, 87, 91-120.

Brown, S., Hillegeist, S.A., Lo, K., (2009). The Effect Of Earnings Surprises On Information Asymmetry. J. Account. Econ. 47, 208-225.

Burns, N. And Kedia, S. (2006), "The Impact Of Performance-Based Compensation On Misreporting”, Journal Of Financial Economics, Vol. 79 No. 1, Pp. 35-67.

Chen, E., Gavious.,I \& Yosef.,R. (2013). The Relationship Between The Management Of Book Income And Taxable Income Under A Moderate Level Of Book-Tax Conformity. Journal Of Accounting, Auditing \& Finance 28(4) 323-347

Cheng, Q. And Warfield, T.D. (2005) Equity Incentives And Earnings Management, The Accounting Review, Vol.80(2), Pp. 441-476.

Chi-Hsiou D. Hung, Yuxiang Jiang, Frank Hong Liu , Hong Tu , (2018) Competition Or Manipulation? An Empirical Evidence Of Determinants Of The Earnings Persistence Of The U.S. Banks, Journal Of Banking And Finance

Chou., Y.,Y And Chan.,M .,L (2018) The Impact Of Ceo Characteristics On Real Earnings Management: Evidence From The Us Banking Industry, Journal Of Applied Finance \& Banking, Vol. 8, No. 2, 17-44 Issn: 1792-6580 (Print Version), 1792-6599 (Online) Scienpress Ltd, 2018

Cohen, D., Zarowin, P., (2010. Accrual-Based And Real Earnings Management Activities Around Seasoned Equity Offerings. J. Account. Econ. 50 (1), 2-19.

Dechow, P. M \& Ge, W. (2006). The Persistence Of Earnings And Cash Flows And The Role Of Special Items. Implications For The Accrual Anomaly. Vol. 11, Pp: 253-296.

Dechow, P., Ge, W., And Schrand, C. (2010) Understanding Earnings Quality: A Review Of Their Proxies, Their Determinants And Their Consequences, Journal Of Accounting And Economics, Vol. 50, Pp. 344401.

Dridi, W., \& Adel, B. (2016). Book-Tax Differences And The Persistence Of Earnings And Accruals: Tunisian Evidence. Asian Social Science, 12(6), 193-202

Fairfield, P. M., Scott, W \& Teri, L. (2003). The Differential Persistence Of Accruals And Cash Flows For Future Operating Income Versus Future Return On Assets. Review Of Accounting Studies. Vol. 8, Pp : 221243

Frank, M. M., Lynch, L. J., And Rego, S. O. (2009). “Tax Reporting Aggressiveness And Its Relation To Aggressive Financial Reporting”. The Accounting Review, 84 (2), 467-496.

Goncharov, I., \& Zimmermann, J. (2006). Earnings Management When Incentives Compete: The Role Of Tax Accounting In Russia. Journal Of International Accounting Research, 5, 41- 65.

Hanlon, M. (2005), "The Persistence And Pricing Of Earnings, Accruals, And Cash Flows When Firms Have Large Book-Tax Differences", The Accounting Review, 80 (1), 137-166

Hanlon, M., Maydew, E., \& Shevlin, T. (2008). An Unintended Consequence Of Book-Tax Conformity: A Loss Of Earnings Informativeness. Journal Of Accounting And Economics, 46(2-3), 294-311.

Jackson, M. (2009), "Book-Tax Differences And Earnings Growth", Working Paper, University Of Oregon

Juliati Dan Heru Tjaraka. (2014). Kemampuan Deferred Tax Expense Dan Current Tax Expense Dalam 
Mendeteksi Earnings Management Di Saat Perubahan Tarif Pajak Penghasilan Badan Tahun 2008-2010 (Studi Pada Perusahaan Manufaktur Di Bursa Efek Indonesia). Simposium Nasional Akuntansi Xvi. Lombok.

Lev, B. And Nissim, D. (2004), “Taxable Income, Future Earnings, And Equity Value”, The Accounting Review, 79 (4), 1039-1074

Liu, A. Z., Schneible.,R. (2017), Analysts' Experience And Interpretation Of Discretionary Accruals In Predicting Future Earnings, Advances In Accounting, Vol. 27 No. 4, Pp. 328-345.

Machdar, N., M., Manurung, A., H., Murwaningsari, E., (2017) The Effects Of Earnings Quality, Conservatism, And Real Earnings Management On The Company'S Performance And Information Asymmetry As A Moderating Variable. International Journal Of Economics And Financial Issues, 7(2), 309-318.

Madi Almadi, Philip Lazic, (2016) "Ceo Incentive Compensation And Earnings Management: The Implications Of Institutions And Governance Systems", Management Decision, Vol. 54 Issue: 10, Pp.2447-2461,

Martinez, A.L. And De Souza, T.B.T. (2015), "Book-Tax Differences, Earnings Persistence And Tax Planning Before And After The Adoption Of Ifrs In Brazil", Working Paper, Ix Congresso

Morgenson, G. (2013), "An Unstoppable Climb In Ceo Pay", The New York Times, June 30, New York, Ny,

Neokleous, C. I. (2015). Executive Compensation As A Corporate Governance Problem. Essex Student Research Online, 7, 27- 41.

Noor, R. M., Mastuki, N., \& Bardai, B. (2009). Book-Tax Difference And Value Relevance Of Taxable Income: Malaysian Evidence. Journal Of Financial Reporting And Accounting, 7(2), 19-40

Penman, Stephen H. (2001). Financial Statement Analysis And Security Valuation. Singapore: Mc Graw Hill.

Phillips, J., Pincus, M. And Rego, S. (2003), "Earnings Management: New Evidence Based On Deferred Tax Expense", The Accounting Review 78: 491-521

Rakia Riguen Koubaa, Anis Jarboui, (2017) "Direct And Mediated Associations Among Earnings Quality, Book-Tax Differences And The Audit Quality", Journal Of Financial Reporting And Accounting, Vol. 15 Issue: 3 , Pp.293-316

Roychowdhury, S., (2006). Management Of Earnings Through The Manipulation Of Real Activities That Affect Cash flow From Operations. Journal Of Accounting And Economics 42, 335-370.

Sonnier, B.M., Hennig, C.J., Everett, J.O., Raabe, W.A. (2012), "Reporting Of Book-Tax Differences For Financial And Tax Purposes: A Case Study", Journal Of Accounting Education, 30, 58-79

Sugiyanto., Murwaningsari, E., (2017) Earning Management, Risk Profile And Efficient Operation In The Prediction Model Of Banking : Eviden From Indonesia. Ijsrst, Vol. 4, Issue 5, 2395-6011

Sundvik, D. (2017). Book-Tax Conformity And Earnings Management In Response To Tax Rate Cuts. Journal Of International Accounting, Auditing And Taxation, 28, 31-42

Tuukka Järvinen And Emma-Riikka Myllymäki (2016) Real Earnings Management Before And After Reporting Sox 404 Material Weaknesses. Accounting Horizons: March 2016, Vol. 30, No. 1, Pp. 119-141.

Waluyo (2016). The Relationship Between Book-Tax Differences And Earnings Growth Within Indonesian Manufacturing Firms. Research Journal Of Finance And Accounting Issn 2222-1697 (Paper) Issn 22222847 (Online) Vol.7, No.18, 2016

Watson, J \& Wells, P. (2005). The Association Between Various Earnings And Cash Flow Measures Of Firm Performance And Stock Returns: Some Australian Evidence.

Whitaker, C. (2006). How To Build A Bridge: Eliminating The Book-Tax Gap. The Tax Lawyer 59.

Wijayanti, Handayani Tri. (2006). Analisis Pengaruh Perbedaan Antara Laba Akuntansi Dan Laba Fiskal Terhadap Persistensi Laba, Akrual, Dan Arus Kas. Paper Dipresentasikan Pada Simposium Nasional Akuntansi Ix, Padang.

Xian.,C, Sun,.F. Zhang.Y, (2015) "Book-Tax Differences: Are They Affected By Equity-Based Compensation?", Accounting Research Journal, Vol. 28 Issue: 3, Pp.300-318,

Zang, A., (2012). Evidence On The Trade-Off Between Real Activities Manipulation And Accrual-Based Earnings Management. Account. Rev. 87 (2), 675-703.

Zhou, M. (2016). Does Accounting For Uncertain Tax Benefits Provide Information About The Relation Between Book-Tax Differences And Earnings Persistence? Review Of Accounting And Finance, 15(1), 6584 